This is an electronic reprint of the original article. This reprint may differ from the original in pagination and typographic detail.

Author(s): Roiha, Anssi

Title: $\quad$ Teachers' views on differentiation in content and language integrated learning (CLIL): Perceptions, practices and challenges

Year: $\quad 2014$

Version:

Please cite the original version:

Roiha, A. (2014). Teachers' views on differentiation in content and language integrated learning (CLIL): Perceptions, practices and challenges. Language and education, 28(1), 1-18. https://doi.org/10.1080/09500782.2012.748061

All material supplied via JYX is protected by copyright and other intellectual property rights, and duplication or sale of all or part of any of the repository collections is not permitted, except that material may be duplicated by you for your research use or educational purposes in electronic or print form. You must obtain permission for any other use. Electronic or print copies may not be offered, whether for sale or otherwise to anyone who is not an authorised user. 


\section{Teachers' views on differentiation in Content and Language Integrated Learning (CLIL): Perceptions, practices and challenges}

\begin{tabular}{|c|c|}
\hline Journal: & Language \& Education \\
\hline Manuscript ID: & LE-1309 \\
\hline Manuscript Type: & Paper \\
\hline Keywords: & $\begin{array}{l}\text { CLIL, inclusion, differentiation, the perceptions of differentiation, the } \\
\text { challenges of differentiation, teacher }\end{array}$ \\
\hline Abstract: & $\begin{array}{l}\text { The present study investigates differentiation in Content and Language } \\
\text { Integrated Learning (CLIL) in Finland. Specifically, this combination of a } \\
\text { qualitative case study and quantitative survey examines (1) primary } \\
\text { teachers' perceptions of differentiation, ( } 2 \text { ) the differentiation methods } \\
\text { specific to CLIL education the teachers use and ( } 3 \text { ) the challenges of } \\
\text { differentiation they identify. The qualitative phase was conducted in a } \\
\text { school which offers CLIL education also to pupils with special needs } \\
\text { following the principles of inclusive education. The results revealed that the } \\
\text { teachers ( } \mathrm{n}=51 \text { ) perceived differentiation in somewhat different ways. In } \\
\text { general, the teachers differentiated their CLIL education in a fairly versatile } \\
\text { manner with various teaching arrangements and methods and focussed on } \\
\text { the differentiation of the language. In addition, the teachers' perceptions of } \\
\text { differentiation correlated with the differentiation practices they used. The } \\
\text { greatest challenges of differentiation involved time, material and physical } \\
\text { classroom environment. The study indicates that teachers should be more } \\
\text { conscious of the nature of differentiation for it to be more purposeful and } \\
\text { systematic. Schools should critically re-examine their structures and for } \\
\text { instance co-teaching, class-size reduction or remedial teaching could be } \\
\text { used more effectively. }\end{array}$ \\
\hline
\end{tabular}

\section{SCHOLARONE \\ Manuscripts}




\title{
Teachers' views on differentiation in Content and Language Integrated Learning (CLIL): Perceptions, practices and challenges
}

\begin{abstract}
The present study investigates differentiation in Content and Language Integrated Learning (CLIL) in Finland. Specifically, this combination of a qualitative case study and quantitative survey examines (1) primary teachers' perceptions of differentiation, (2) the differentiation methods specific to CLIL education the teachers use and (3) the challenges of differentiation they identify. The qualitative phase was conducted in a school which offers CLIL education also to pupils with special needs following the principles of inclusive education. The results revealed that the teachers $(n=51)$ perceived differentiation in somewhat different ways. In general, the teachers differentiated their CLIL education in a fairly versatile manner with various teaching arrangements and methods and focussed on the differentiation of the language. In addition, the teachers' perceptions of differentiation correlated with the differentiation practices they used. The greatest challenges of differentiation involved time, material and physical classroom environment. The study indicates that teachers should be more conscious of the nature of differentiation for it to be more purposeful and systematic. Schools should critically reexamine their structures and for instance co-teaching, class-size reduction or remedial teaching could be used more effectively.
\end{abstract}

Keywords: CLIL education, inclusion, differentiation, the perceptions of differentiation, the challenges of differentiation, teacher

\section{Introduction}

The present research examines differentiation in CLIL education which Finnish legislation has allowed schools to practise since 1991. This resulted in a rapid increase of CLIL education in Finland and for instance in 1996 almost 10 per cent of comprehensive schools reported implementing it (Nikula and Marsh 1996). The popularity of CLIL education has decreased considerably since then as in 2005 only less than five per cent of comprehensive schools provided it (Lehti, Järvinen and Suomela-Salmi 2006). However, the latest report on the issue reveals that there is again a growing interest in CLIL education in many municipalities (Kangasvieri et al. 2011).

The main aim of the present study is to address the issue of how to support pupils with special needs in CLIL education by means of differentiation. Traditionally most CLIL pupils have been pretested and chosen to CLIL education based on their linguistic abilities and general school performance. Hence, the number of pupils with special needs in CLIL classes has been relatively small and the previous CLIL research has thus neglected them. However, in some schools, including the target school in the qualitative phase of the present research, CLIL education is provided to all pupils regardless of their skills or abilities. Such inclusive policy results in very heterogeneous classrooms with different types of learners and causes challenges to teaching.

In Finland, a greater emphasis is placed on differentiation also due to a new structural change which may partly increase the number of underachieving pupils in CLIL education. That is, the Finnish Basic Education Act and the Finnish National Core Curriculum for Basic Education (FNCCBE) were amended in 2010 regarding the issue of support for underachieving pupils and a new threefold support model was introduced. One aim of the model was to reduce unnecessary transfers to special needs education as the number of pupils attending it had been steadily increasing for several years (e.g. Kivirauma and Ruoho 2007; Saloviita 2009; Lintuvuori 2010). The three stages of the model are called general support, enhanced support and special-needs support (Amended Basic Education Act [ABEA] 2010; 
Amendments and Additions to the National Core Curriculum for Basic Education [AANCCBE] 2010). The threefold support model is built on the idea that underachieving pupils should receive support with various methods at the two first levels of the model in order to avoid entering the last stage of the model. That is, the special-needs support which corresponds to the previous transfer to special needs education. Differentiation is one of the most central support methods in all stages of the threefold support model. Thus, the present research delves into two fairly current issues in the field of education in Finland, differentiation and CLIL education. Previous research has mostly examined the two issues separately and not integrated them.

This paper presents the study conducted for the researcher's master's thesis. First, the theoretical framework, which builds on the terms CLIL, inclusion and differentiation, is introduced. Second, the methodology of the research and the research questions are described. Third, the results from both study phases are jointly presented although the phases were conducted separately. The results section contains quotes from the teachers in the qualitative phase which are translated into English by the researcher (original language Finnish). Last, the results of the study are further analysed and the main implications derived from them are discussed.

\section{Theoretical framework}

\section{CLIL}

Research on CLIL education has focussed on its impact on pupils' school attainment. For instance, the results as regards the effects of CLIL education on pupils' foreign language development and affective features have been extremely positive (e.g. Järvinen 1999; Lasagabaster 2008, 2011; Ruiz de Zabore 2008; Lorenzo, Casal and Moore 2009; Admiraal, Westhoff and de Bot 2006; Pihko 2007). The results of the effects of CLIL education on content learning have been slightly less consistent. However, several studies indicate that CLIL education has a fairly positive effect also on pupils' content learning and general school performance (e.g. Jäppinen 2005; Seikkula-Leino 2007).

Previous CLIL research has only referred to the issues of differentiation or pupils with special needs in general. For instance, Pihko's (2010) research, which examined pupils' (n = 209) experiences in CLIL education, touched on the issue of differentiation. She found that some pupils wanted teachers to individualise their teaching and use L1 (Finnish) more. Seikkula-Leino (2005) deduces that underachieving pupils could participate in CLIL education more as her study indicates that they can obtain similar results in CLIL education than in traditional one. She however reminds that this would require increased resources and greater pedagogical knowledge. Meriläinen (2008) investigated the ways to support different types of learners in one English speaking immersion education class in Finland. She found that the use of L1 (Finnish) and flexible grouping were common and effective methods to support the learning of underachieving pupils. Meriläinen (2008) states that schools should pay attention to various issues in CLIL education such as core subjects and content, the role of L1 and L2, assessment, teaching methods and learning strategies.

\section{Inclusion}

Inclusion has been widely studied. For instance, Peterson and Hittie (2003, 35-42) have summarised the results of numerous inclusion studies and meta-analyses that have examined the effect of inclusion on pupils' academic achievement and social well-being. With few exceptions, the results have been highly positive. In their meta-analysis Kalambouka et al. 
(2007) summarise 26 inclusion studies that examined the impact of inclusion on the academic performance and social development of pupils without special needs. The results were positive or neutral in approximately 80 per cent of the studies, which indicates that integrating pupils with special needs into general education classes does not have a negative influence on other pupils' school performance or social development.

Despite the encouraging research results concerning the effects of inclusion on pupils' attainment and social well-being, people's attitudes towards inclusion have not been very positive. For instance, in a large survey for class teachers, subject teachers, special needs teachers and principals $(n=1,824)$, Moberg (2001) found that only five per cent of the participants supported inclusion to some extent. The vast majority of the teachers objected inclusion as they feared not being able to provide quality teaching for both pupils with and without special needs. According to Moberg (2001) this type of view reveals that teachers value pupils' maximal academic performance more than teaching pupils physically in the same classroom. Eight years later, Kuorelahti and Vehkakoski (2009) obtained similar results to Moberg's (2001) study in their survey in which 1,034 parents, 233 teachers and 44 principals participated.

\section{Differentiation}

Differentiation is not regarded as a theory of its own, but rather a synthesis of several different theories. For instance, differentiation has traces of Gardner's Theory of Multiple Intelligences and can be considered as its pedagogical application (e.g. Gardner 2008; see also Tomlinson and Allan 2000, 21). Gardner's theory recognises that pupils are different in terms of their intelligences and talents and thus implies that teaching should be adapted to best match each pupil's individual abilities and needs. Another theoretical concept that is central to differentiation is Vygotsky's (1978, 1982) Zone of Proximal Development (ZPD) (see also Tomlinson and Allan 2000, 18-19). The aim of differentiation is to discover the pupil's actual development stage and tailor teaching so that it corresponds to the pupil's ZPD. Therefore, in an ideal situation of differentiation each pupil would be working in his or her own personal ZPD.

In practice, differentiation can be implemented on three dimensions: the extent, the depth and the progress rate of studying (AANCCBE 2010, 6). Teachers can thus differentiate the goals, content, teaching methods, materials and tasks, learning environments and assessment according to pupils' readiness, interests, abilities, motivation and self-esteem (Tomlinson 1999, 11; Moberg and Vehmas 2009, 64; UNESCO 2004, 14; Ikonen, Ojala and Virtanen 2003, 144; AANCCBE 2010, 5-6) (see Figure 1).

[Figure 1 near here].

Previous research has been examining different aspects of differentiation. For instance, Berbaum (2009), Naukkarinen (2005) and Mikola (2011) have investigated teachers' perceptions of differentiation. Their studies reveal that many teachers perceive differentiation in a somewhat narrow way and often focus merely on differentiating the tasks and assignments. In addition, teachers have identified numerous challenges for successful differentiation which include large class sizes, lack of time and resources and lack of knowledge of differentiation. Another approach in research has been to scrutinise the effects of differentiation on pupils' achievement. Research shows that in general differentiation has a positive effect on both underachieving and gifted pupils' school achievements. Furthermore, pupils have found the differentiation methods motivating and easy to employ (e.g. 
DeBaryshe, Gorecki and Mishima-Young 2009; McCrea Simpkins, Mastropieri and Scruggs 2009; Reis et al. 2011).

\section{Methodology and research questions}

\section{Data collection and analysis}

The present research is a combination of a qualitative case study and quantitative survey. The aim of the qualitative study phase was to increase the understanding and knowledge of differentiation as a phenomenon in inclusive CLIL education by means of a case study in order to become more aware of the different practical differentiation methods one can use. The qualitative data were gathered by interviewing teachers $(n=3)$. The teachers were selected from the target school which followed the principles of inclusive education and provided CLIL education to all of the pupils. In addition, the special needs education of the area was centred to the school and each class thus had approximately two pupils with special needs. The qualitative data collection was conducted in October and November 2011. The transcribed interviews and observation notes were organized under themes and analysed following theory oriented content analysis methods (e.g. Tuomi and Sarajärvi 2009).

The quantitative study phase investigated how the results of the qualitative phase appear in CLIL education in general and thus provided an overview of differentiation in CLIL education. The quantitative data $(n=48)$ were gathered using a survey based on the findings of the qualitative phase and were analysed with the SPSS 20.0 programme. Altogether the survey consisted of 31 ways to differentiate CLIL education. The quantitative data collection was conducted in April and May 2012. An internet-based survey which consisted of three sections was sent to 143 CLIL teachers in Finland who taught English CLIL education at primary school level. The survey was answered by 48 teachers which provided a response rate of 33.6 per cent.

The statistical analysis of the quantitative data was mainly based on descriptive statistics such as frequencies, percentages, means and standard deviations. In addition, a set of variables were summed together to produce five new variables that contained the total value of each category and their correlations were calculated using Pearson's correlation coefficient. The five new variables corresponded to (1) the teachers' perceptions of differentiation, (2) the methods the teachers used to differentiate their CLIL education for underachieving pupils, (3) the methods the teachers used to differentiate their CLIL education for gifted pupils, (4) the methods the teachers used to differentiate their CLIL education for both underachieving and gifted pupils and (5) the challenges of differentiation the teachers identified (see Table 1).

\section{Reliability and validity}

The reliability of the quantitative phase was examined by means of internal consistency which was measured with Cronbach's alpha. The values of alpha for all the five combined variables were above 0.60 which can be seen as the lowest acceptable value and were thus regarded as sufficiently reliable (see Table 1).

[Table 1 near here].

As regards the validity of the research, the sample was gathered following the principles of a random sample. The population of the present research was estimated to be approximately 500 primary school teachers who practise English CLIL education in Finland. Therefore, on a confidence level of 95 per cents the response rate of 33.6 per cent produced the confidence 
interval (margin of error) of 13.46. Hence, it is important to note that the generalisations of the quantitative results are fairly limited.

\section{Participants}

The participants in the qualitative phase were three CLIL teachers $(n=3)$ of the target school which follows the policy of inclusive education and offers CLIL education also to pupils with special needs. As Table 2 shows, the teachers represented very different characteristics.

[Table 2 near here].

Teacher2 was the only one who also had the qualification of a special needs teacher. She was also the only one who worked as a full-time teacher as Teacher1 and Teacher3 were class teachers. In addition to the pupils who received enhanced or special-needs support, some pupils received individual support from the special needs teacher either occasionally or regularly. In this research, gifted pupils were defined as pupils whose general school attainment was good and whose language skills were clearly above average. The number of them was based only on the teachers' estimations.

The participants in the quantitative phase were 48 CLIL teachers $(n=48)$ from different parts of Finland. Four of them were male and 44 of them female. Their average CLIL education experience was approximately eight years. The teachers taught different age groups: from the first to the sixth grade the mode being the fifth grade. In general, the class sizes were fairly small as only four participants had more than 25 and more than half of the teachers had 21 to 25 pupils in their class. On average, the teachers had 1.5 pupils with special needs and 6.1 gifted pupils in their classroom.

\section{Research questions}

The present study poses the following research questions:

1. How do the teachers in the target school perceive the concept of differentiation? (qualitative phase)

2. How do they differentiate their teaching in inclusive primary school CLIL education in practice? (qualitative phase)

3. What challenges do they identify for differentiation in inclusive primary school CLIL education? (qualitative phase)

4. In general, how do teachers view differentiation in CLIL education? (quantitative phase)

\section{Results}

\section{Perceptions of differentiation}

The teachers perceived differentiation in somewhat different ways. In the interviews, Teacher2 had the broadest view on differentiation as she understood it as taking pupils' individuality into account in general. She further considered that pupils' personality should be at the core of differentiation and pupils' social objectives should also be differentiated. Teacher1 and Teacher3 on the other hand had a narrower view on differentiation as they mainly regarded it as modifying the tasks and teaching methods based on pupils' needs. Most 
teachers in the quantitative phase ( $88 \%$ of the participants) agreed with Teacher2's broader view on differentiation. However, all three teachers in the qualitative phase considered differentiation to involve all pupils whereas only 26 teachers in the quantitative phase $(54 \%$ of the participants) considered similarly. All the teachers in the qualitative phase regarded differentiation as highly important and agreed that differentiation for underachieving pupils was more important than for gifted pupils. For instance, Teacher2 noted the following on the issue:

I think it is even more dangerous, even downright somehow unethical not to help the one who is left out because (s)he doesn't know or isn't able to... the gifted one always has a chance to participate, but those who can't do it don't have too many of those chances. (Teacher2)

Most teachers in the quantitative phase ( $75 \%$ of the participants) considered both dimensions of differentiation to be equally important. However, 12 teachers ( $25 \%$ of the participants) considered differentiation for underachieving pupils to be more important than for gifted pupils whereas none of the teachers regarded differentiation for gifted pupils as more important.

The level of difficulty of the two differentiation dimensions was an issue which divided the teachers more. That is, according to Teacher1, differentiation for both learner types was equally challenging. Teacher2, in turn, considered that it is easier to differentiate for underachieving pupils whereas Teacher3 had the exact opposite view. In the quantitative phase, the majority of the teachers (54\% of the participants) regarded both dimensions of differentiation as equally challenging. However, more teachers (33\% of the participants) considered differentiation for underachieving pupils easier than for gifted pupils. Only six teachers (13\% of the participants) regarded differentiation for gifted pupils as more effortless.

\section{Differentiation in practice}

The three teachers interviewed mentioned several practical methods how CLIL education can be differentiated. The following subcategories emerged from the interviews: the planning and implementation of the teaching, individual assistance and peer support, tasks, special needs assistant and the role of L2 and L1. The use of these methods was then further examined among the CLIL teachers in the quantitative phase. In addition, few methods were added to the survey which were not mentioned in the interviews but are generally considered as traditional methods of differentiation.

Out of the 31 methods, 12 were frequently used by more than 70 per cent of the teachers in the differentiation of their CLIL education. Furthermore, five methods were commonly used by at least half of the teachers. The most often employed method in the differentiation for underachieving pupils was to provide extensive visual and oral support during the teacher talk which all the teachers (100\% of the participants) reported using. Other often employed methods were allowing pupils to use L1 (Finnish), making use of peer support, discussing issues together with the whole class and flexible grouping (temporarily grouping pupils according to their abilities) which were all used by 73 per cent of the teachers (see Table 3 ).

[Table 3 near here].

The most often employed differentiation method for gifted pupils was discussing with them in L2 (English) which 36 teachers (82\% of the participants) reported using. Other common methods were guiding the gifted pupils towards L2 (English) production which was used by 
35 teachers ( $80 \%$ of the participants) and providing them with additional material which 31 teachers $(71 \%$ of the participants) stated using (see Table 4$)$.

[Table 4 near here].

Four commonly used differentiation methods could be used for both dimensions of differentiation. For instance, expecting individual accomplishment of the similar tasks, individual support and presentations and projects which pupils produce according to their individual abilities were methods that were used by 71 per cent of the teachers. In addition, more than half of the teachers (52\% of the participants) reported setting different objectives for different pupils as a way to differentiate their CLIL education (see Table 5).

[Table 5 near here].

Out of the 31 methods, only five were infrequently employed by the teachers. The most seldom practised method was providing additional teaching for gifted pupils, which 32 teachers ( $72 \%$ of the participants) stated never or hardly ever using. Other rarely employed differentiation methods in CLIL education were co-teaching, special needs assistant or remedial teaching for underachieving pupils.

The teachers employed several differentiation methods in a versatile manner. First, writing assisting markings to the L2 (English) texts of the pupils with special needs was a method which was often used by 14 teachers (32\% of the participants) but seldom used by 15 of them (34\% of the participants). Second, different homework for different pupils was a method which was commonly utilised by 16 teachers (36\% of the participants) but infrequently utilised by 14 teachers (32\% of the participants). Third, informing the pupils about the topic of the CLIL lesson beforehand was a method which was often employed by 14 teachers (32\% of the participants) but seldom employed by 16 teachers $(36 \%$ of participants). The following quote from Teacher3 well illustrates how effective the latter differentiation method can be for some pupils:

At least with my previous class it was... when there were those pupils for whom the CLIL lessons were very very arduous so with them I noticed that sometimes for instance when going to the previous break I told them with few sentences that what the [CLIL] topics are and all. I felt that it calmed them down. This kind of extra anxiety from those pupils who are even normally quite anxious was gone now that they were at least a little aware of what we talked about although at the moment they didn't know what I said but they knew that this is about this topic from what I had told them beforehand. (Teacher3)

\section{Challenges of differentiation}

The present research revealed various challenges for differentiation in CLIL education. The greatest challenges identified by the three teachers in the qualitative phase were the lack of time and resources, the material and the large class sizes. Teacher3 stated the following on the issue:

This is so eclectic this teacher's job description nowadays that.. I've heard stories that sometimes it has been less eclectic that.. that probably it is purely this kind of lack of time and strengths.. sensible use of your strengths are the things that affect it the most.. so like I said that I think that in an ideal world many teachers would differentiate much more than they actually do in practice.. (Teacher3) 
The teachers in the survey regarded the same issues as most challenging for differentiation in CLIL education (see Table 6). Furthermore, the impracticality of the physical classroom settings was considered as a major challenge, which was also mentioned by Teacher1 and Teacher2 in the interviews.

[Table 6 near here].

The least challenging issues for differentiation in CLIL education were the lack of knowledge of their pupils which 34 teachers ( $83 \%$ of the participants) in the quantitative phase did not consider as a challenge. This challenge was raised by Teacher2 who worked as a full-time teacher at her school. Other issues which were regarded as minor challenges were cooperation with other school staff members and the lack of knowledge of the practical differentiation methods (see Table 7).

[Table 7 near here].

Some challenges clearly divided the teachers' opinions. Fifteen teachers $(37 \%$ of the participants) in the quantitative phase considered the fact that other matters take time and energy away from differentiation as a great challenge whereas 14 teachers $(34 \%$ of the participants) regarded it as a minor one. The heterogeneous classrooms were seen as a great challenge by 16 teachers ( $39 \%$ of the participants) and a minor one by 10 teachers ( $24 \%$ of the participants).

\section{Correlations}

Correlations were also analysed from the data. A statistically significant and fairly strong relationship was found between the teachers' perceptions of differentiation and the ways they differentiated their CLIL education in practice $(\mathrm{r}=.424 ; \mathrm{p}=.004)$. The correlation between both dimensions of differentiation (i.e. for underachieving and gifted pupils) was also fairly strong and statistically significant $(r=.440 ; p=.003)$ as was the case between the number of pupils with special needs and the ways the teachers differentiated their CLIL education in practice $(\mathrm{r}=.432 ; \mathrm{p}=.003)$. Although the correlations were fairly tentative, they still indicate that the broader views on differentiation teachers have, the more likely they are to differentiate in practice. In addition, the correlations suggest that teachers who differentiate their CLIL education often do it in a fairly wide manner and use a variety of practical methods for both dimensions of differentiation. Furthermore, the findings imply that the teachers who have pupils with special needs in their classes differentiate their CLIL education in practice more.

\section{Discussion}

The results of the present study support the earlier findings that teachers perceive differentiation in somewhat different ways (e.g. Berbaum 2009; Naukkarinen 2005; Mikola 2011). Furthermore, the correlations imply that there is a relationship between teachers' perceptions and the practical differentiation methods they use. It is thus very important that teachers would be more aware of the nature of differentiation. The broader teachers consider differentiation, the more purposeful and systematic their practical differentiation is. Schools should also form their own policies and practices of differentiation and teachers should share their views and experiences more. The present research also implies that some teachers regard differentiation as a somewhat separate issue which does not automatically belong to teaching. 
However, as Tomlinson and Imbeau (2010) state differentiation should be at the core of teaching and therefore not crucially increase teachers' workload.

The present research confirms that most teachers regard differentiation for underachieving pupils as more important than for gifted pupils. In addition, most teachers consider differentiation for gifted pupils to be more challenging than for underachieving pupils. It is important however to focus also on differentiation for the gifted pupils as they may get frustrated if school does not provide them with sufficient challenges (KeltikangasJärvinen 2006, 190). In particular in CLIL education, the number of gifted pupils has traditionally been above average as pupils are often pretested. Differentiation is based on the idea that teaching should be modified to meet everyone's individual needs and abilities (e.g. Bender 2008, 6; Tomlinson, Brimijoin and Narvaez 2008, 4). Hence, in an ideal situation all the pupils would work on their own ZPD (see Vygotsky 1982, 184-186).

Contradictory to some previous studies (e.g. Berbaum 2009; Naukkarinen 2005: Mikola 2011) the teachers in the present study did not differentiate their CLIL education by providing pupils with different tasks. On the contrary, a commonly used method was to provide pupils with similar tasks but require their individual accomplishment. One explanation for this could be that in general the material issue in CLIL education is seen as a challenge (Lehti, Järvinen and Suomela-Salmi 2006). Suitable and reliable material for all the subjects is not always available and teachers often have to rely for instance on internet sources. In these cases it must be ensured that the material is not too challenging for the pupils and that it also fits with the FNCCBE (2004). One solution for schools to tackle the material issue is to start producing their own material which can be used with different classes. All in all, the material problem itself reflects teachers' somewhat constricted and task-based view on differentiation. Furthermore, if differentiation is strongly present in teacher's teaching philosophy not all differentiation practices need to be explicitly stated in the material.

Differentiation can be viewed both as an individual level or a group level process. The teachers in the present study took the social aspect of differentiation into account fairly well. For instance, most teachers employed peer support in differentiation in CLIL education. In addition, approximately one fifth of the teachers stated that too excessive differentiation hinders collaborate learning. Interestingly, the view itself reveals that teachers regard differentiation more as an individual level than as a group level process. Nevertheless, the teachers' concerns reflect the idea that learning in general is seen as an interactive process. One pedagogical solution to the issue is flexible grouping which was used by some of the teachers in the present research and is also introduced as a differentiation method in the AANCCBE $(2010,15,18,20)$. Teachers can temporarily group pupils according to their abilities which enables more effective and suitable teaching for the pupils.

The present study reveals that language is an important issue of differentiation in CLIL education. In previous research, teachers have had different views on the role of L1 and L2. That is, some teachers have regarded it as important not to use any L1 in CLIL education whereas others have not felt that strictly about the occasional use of it (e.g. Nikula and Marsh 1997; Meriläinen 2008). In the present research, all three teachers interviewed used L1 (Finnish) in supporting the underachieving pupils' learning in CLIL education and also mentioned it as a way to consider pupils' affective features. The vast majority of the teachers answering the survey acted similarly. Pihko's (2010) research reveals that pupils would like teachers to use even more L1 in CLIL education. As regards the pupils' language use, the teachers in this study had fairly similar views: all but five teachers allowed pupils to use their mother tongue in CLIL lessons. In general, too excessive use of pupils' L1 in CLIL education may lead to a situation where pupils' do not even attempt to understand challenging L2 input as they take it for granted that the same is said also in their L1. However, employed in a systematic and justifiable way the use of L1 can be an effective method in supporting the 
underachieving pupils' participation in CLIL education. Furthermore, the use of L1 is also justified by the principle of CLIL education that the content learning exceeds the importance of L2 learning (see also FNCCBE 2004, 270-273).

The obstacles for successful differentiation are often certain structural and schoolcultural factors such as large class sizes, the lack of school assistants or the lack of opportunities to practise co-teaching (e.g. Tomlinson and Imbeau 2010; Berbaum 2009; Naukkarinen 2005; Mikola 2011; Seppälä and Kautto-Knape 2009), which the present research verifies. Indeed, the teachers in general did not use co-teaching in the differentiation in CLIL education. Schools still have a fairly strong individualistic culture and teachers are considered to be alone in charge of the teaching and planning of their classes. Increased cooperation between teachers and different professionals at school would benefit teaching and also differentiation. Despite the fact that none of the teachers in the qualitative phase practised co-teaching in CLIL education, interestingly all of them considered it as a beneficial method and were willing to try it. The AANCCBE (2010) also encourages teachers to co-operate more as it is seen as a vital asset regarding differentiation. In addition, a recent study proves that co-teaching is an effective working method both from teachers' and pupils' perspectives (Ahtiainen et al. 2011).

The present research raises several other structural and school-cultural issues worth reexamining. First, remedial teaching was a method which was generally very seldom used in the differentiation in CLIL education. However, it has been stated as a useful differentiation method already in the FNCCBE (2004) and is a central method also in the new threefold support model (AANCCBE 2010, 20-21). Seikkula-Leino (2005) has introduced it as an important method to differentiate CLIL education already almost ten years ago. Remedial teaching could focus on supporting the underachieving pupils either before or after the CLIL lessons. The language of instruction in remedial teaching could be pupils' L1 (Finnish) as was the case in Meriläinen's (2008) case study. Second, large class sizes and the physical classroom settings were regarded as major challenges in differentiation in CLIL education which is in accordance with previous research (e.g. Naukkarinen 2005; Mikola 2011; Seppälä and Kautto-Knape 2009). One solution to tackle the problem of large class sizes in differentiation is to practise CLIL education with smaller groups. Pihko's (2010) research reveals that pupils even prefer smaller group sizes in CLIL education as they consider them as safer learning environments. In addition, flexible grouping, which was discussed earlier, is emphasized with large classes. Teachers could also pay more attention to the decoration and arrangements of the classrooms. For instance, arranging pupils' desks in certain way can bring more space to the classroom and provide more areas for differentiation. Additionally, other school facilities or outside school facilities could be used more effectively in differentiation in CLIL education (see also Ikonen, Ojala and Virtanen 2003, 144; AANCCBE 2010, 6).

\section{Conclusion}

It should be noted that the research had some limitations. Firstly, the results are mainly based on the teachers' own perceptions and statements of their behaviour which can be contradictory to their practical actions as some previous studies have shown (see e.g. Qian 2004; also Grönfors 2010). Secondly, the small sample size limited the analysis and the results obtained in the quantitative phase.

The present research gave a preliminary overview of the situation of differentiation in CLIL education in Finland. First, teachers seem to generally differentiate their CLIL education in a fairly versatile manner with various methods. The differentiation practices employed in CLIL education seem to be a mixture of methods used in content subjects (e.g. 
Tomlinson 1999; Tomlinson and Eidson 2003; Yatvin 2004; Peterson and Hittie 2003) and in foreign languages (e.g. de Graaff et al. 2007; Montet \& Morgan 2001; Moilanen 2002; Dufva, Vaarala and Pitkänen 2007; Lee 1994). This is quite understandable as both categories are combined in CLIL education. Second, most of the challenges of differentiation raised in this study are consistent with the ones obtained in previous research (e.g. Tomlinson and Imbeau 2010; Berbaum 2009; Naukkarinen 2005; Mikola 2011; Seppälä and Kautto-Knape 2009). This only strengthens the view that it would be vital to re-examine certain structural and school-cultural issues. Furthermore, the new threefold support model builds on the notion that schools must provide extensive support to the pupils who have difficulties in mainstream education. In order to ensure that, certain fairly rigid and old-fashioned school policies and structures must be modified and renewed.

One aim of the present research was to provide practical ways for teachers to consider the diversity of pupils. The research provides a broad repertoire of practical methods from which teachers can obtain models and ideas for their own teaching in CLIL education. The broader function of the present study was to increase the positive attitudes towards inclusion and help develop more efficient methods and ways to facilitate the participation of pupils with special needs in CLIL education. Therefore, the hope is that the present research encourages more schools to provide CLIL education also to pupils with special needs. The research also brought up several issues on differentiation in CLIL education which can be further studied such as pupils' perspective and the effects of differentiation on pupils' attainment.

\section{References}

Admiraal, W., G. Westhoff, and K. de Bot. 2006. Evaluation of bilingual secondary education in the Netherlands: Student's language proficiency in English. Educational Research and Evaluation 12, no. 1: 75-93.

Ahtiainen, R., M. Beirad, J. Hautamäki, T. Hilasvuori, and H. Thuneberg. 2011. Samanaikaisopetus on mahdollisuus: Tutkimus Helsingin pilottikoulujen uudistuvasta opetuksesta [Co-teaching is an opportunity: A study of renewing teaching in pilot schools in Helsinki]. Helsinki, FIN: The Education Department of Helsinki.

Amended Basic Education Act 642/2010. http://www.finlex.fi/en/laki/kaannokset/1998/ en19980628.pdf

Amendments and Additions to the National Core Curriculum for Basic Education. 2010. Helsinki, FIN: The Finnish National Board of Education. http://www.oph.fi/download/ 132551_amendments_and_additions_to_national_core_curriculum_basic_education.pdf

Bender, W. 2008 . Differentiating instruction for students with learning disabilities: Best teaching practices for general and special educators. Thousand Oaks: Corwin Press.

Berbaum, K.A. 2009. Initiating differentiated instruction in general education classrooms with inclusion learning support students: A multiple case study. Doctoral diss., Walden University.

DeBaryshe, B.D., D.M. Gorecki, and L.N. Mishima-Young. 2009. Differentiated instruction to support high-risk preschool learners. NHSA Dialog 2, no. 3: 227-244.

de Graaff, R., G.J. Koopman, Y. Anikina, and G. Westhoff. 2007. An observation tool for effective L2 pedagogy in Content and Language Integrated Learning (CLIL). The International Journal of Bilingual Education and Bilingualism 10, no. 5: 603-624.

Dufva, M., H. Vaarala, and K. Pitkänen. 2007. Vieraat kielet ja monikielisyys [Foreign languages and multilingualism]. In Ymmärsinkö oikein? Kielelliset vaikeudet nuoruusiäss ä [Did I understand right? Language impairment in adolescence], ed. T. Aro, T. Siiskonen, and T. Ahonen, 156-192. Jyväskylä, FIN: PS-kustannus. 
Finnish National Core Curriculum for Basic Education 2004. Helsinki, FIN: The Finnish National Board of Education. http://www.oph.fi/english/publications/2009/national_core curricula_for_basic_education

Gardner, H. 2008. Multiple intelligences: New horizons. New York: Basic Books.

Grönfors, M. 2010. Havaintojen teko aineistonkeräyksen menetelmänä [Observation as a method of data collection]. In Ikkunoita tutkimusmetodeihin 1: Metodin valinta ja aineistonkeruu [Visions for research methods 1: The selection of a method and data collection], ed. J. Aaltola and R. Valli, 154-170. Jyväskylä, FIN: PS-kustannus.

Ikonen, O., T. Ojala, and P. Virtanen. 2003. Yksilöllistäminen opiskelun tukena [Individualisation as a support for studying]. In HOJKS II: Yksilölliset opetussuunnitelmat ja opetus [IEP (individual educational plan) II: Individual syllabi and teaching], ed. O. Ikonen and P. Virtanen, 143-153. Jyväskylä, FIN: PS-kustannus.

Jäppinen, A.-K. 2005. Thinking and content learning of mathematics and science as cognitional development in Content and Language Integrated Learning (CLIL): Teaching through a foreign language in Finland. Language and Education 19, no. 2: 148-169.

Järvinen, H.-M. 1999. Acquisition of English in Content and Language Integrated Learning at elementary level in the Finnish comprehensive school. Doctoral diss., University of Turku, FIN.

Kalambouka, A., P. Farrell, A. Dyson, and I. Kaplan. 2007. The impact of placing pupils with special educational needs in mainstream schools on the achievement of their peers. Educational Research 49, no. 4: 365-382.

Kangasvieri, T., E. Miettinen, H. Palviainen, T. Saarinen, and T. Ala-Vähälä. 2011. Selvitys kotimaisten kielten kielikylpyopetuksen ja vieraskielisen opetuksen tilanteesta Suomessa: Kuntatason tarkastelu [A study of the situation of national language immersion and CLIL education in Finland: A municipality level inquiry]. University of Jyväskylä, FIN: Centre for Applied Language Studies.

Keltikangas-Järvinen, L. 2006. Hyvä itsetunto [Good self-esteem]. 17th ed. Juva, FIN: WSOY.

Kivirauma, J., and K. Ruoho. 2007. Excellence through special education? Lessons from the Finnish school reform. International Review of Education 53, no. 3: 283-302.

Kuorelahti, M., and T. Vehkakoski. 2009. Tukitoimet kunnossa perusopetuksessa? Erityisopetuksen toimivuus ja kouluviihtyvyys oppilaiden, vanhempien ja koulun opetushenkilöstön arvioimana [Support methods in order in basic education? The functionality of special needs education and school contentment assessed by pupils, parents and school staff]. Kuopio, FIN: Snellman-institute.

Lasagabaster, D. 2008. Foreign language competence in Content and Language Integrated courses. The Open Applied Linguistics Journal 1: 30-41.

Lasagabaster, D. 2011. English achievement and student motivation in CLIL and EFL settings. Innovation in Language Learning and Teaching 5, no. 1: 3-18.

Lee, B. 1994. Extending opportunities: Modern foreign languages for pupils with special educational needs. In Teaching modern languages, ed. A. Swarbrick, 88-100. London: Routledge.

Lehti, L., H.-M. Järvinen, and E. Suomela-Salmi. 2006. Kartoitus vieraskielisen opetuksen tarjonnasta peruskouluissa ja lukioissa [An inquiry about the status of CLIL education in comprehensive schools and high schools]. In Kielenoppija tänään - Language learners of today, ed. P. Pietilä, P. Lintunen, and H.-M. Järvinen, 293-313. Jyväskylä, FIN: The Finnish Association of Applied Linguistics.

Lintuvuori, M. 2010. Erityisopetus muutoksen kynnyksellä: Tilastollinen kuvaus erityisopetusjärjestelmästä ja määrällisestä kehityksestä 1970-luvun lopulta vuoteen 
2008 [Finnish special education in change: A statistical description of the Finnish special education system from late 1970 s to present]. Master's thesis, University of Helsinki, FIN.

Lorenzo, F., S. Casal, and P. Moore. 2009. The effects of Content and Language Integrated Learning in European education: Key findings from the Andalusian bilingual sections evaluation project. Applied Linguistics 31, no. 3: 418-442.

McCrea Simpkins, P., M.A. Mastropieri, and T.E. Scruggs. 2009. Differentiated curriculum enhancements in inclusive fifth-grade science classes. Remedial and Special Education 30, no. 5: 300-308.

Meriläinen, M. 2008. Monenlaiset oppijat englanninkielisessä kielikylpyopetuksessa: Rakennusaineita opetusjärjestelyjen tueksi [Diverse children in English immersion: Tools for supporting teaching arrangements]. Doctoral diss., University of Jyväskylä, FIN.

Mikola, M. 2011. Pedagogista rajankäyntiä koulussa: Inkluusioreitit ja yhdessä oppimisen edellytykset [Defining pedagogical boundaries at school: The routes to inclusion and conditions for collaborative learning]. Doctoral diss., University of Jyväskylä, FIN.

Moberg, S. 2001. Opettajien näkemykset inklusiivisesta opetuksesta [Teachers' views on inclusive education]. In Inkluusion haaste koululle: Oikeus yhdessä oppimiseen [The challenge of inclusion for schools: The right for collaborate learning], ed. P. Murto, A. Naukkarinen, and T. Saloviita, 82-95. Jyväskylä, FIN: PS-kustannus.

Moberg, S., and S. Vehmas. 2009. Erityiskasvatuksen perusteet ja käytännöt [The basics and practices of special needs education]. In Erityispedagogiikan perusteet [The basics of special education], ed. S. Moberg, J. Hautamäki, J. Kivirauma, U. Lahtinen, H. Savolainen, and S. Vehmas, 47-73. Helsinki, FIN: WSOY.

Moilanen, K. 2002. Yli esteiden: Oppimisvaikeudet ja vieraat kielet [Across the boundaries: Learning difficulties and foreign languages]. Helsinki, FIN: Tammi.

Montet, M., and C. Morgan. 2001. Teaching geography through a foreign language: how to make text accessible to learners at different levels. Language Learning Journal 24, no. 1: 4-11.

Naukkarinen, A. 2005. Osallistavaa koulua rakentamassa: Tutkimus yleisopetuksen koulun ja erityiskoulun yhdistymisen prosessista [Building an inclusive school: A study of the integration process of a mainstream school and a special education school]. Helsinki, FIN: The Finnish National Board of Education.

Nikula, T., and D. Marsh. 1996. Kartoitus vieraskielisen opetuksen tarjonnasta peruskouluissa ja lukioissa [An inquiry about the status of CLIL education in comprehensive schools and high schools]. Helsinki, FIN: The Finnish National Board of Education.

Nikula, T., and D. Marsh. 1997. Vieraskielisen opetuksen tavoitteet ja toteuttaminen [The goals and implementation of CLIL education]. Helsinki, FIN: The Finnish National Board of Education.

Peterson, J.M., and M.M. Hittie. 2003. Inclusive teaching: Creating effective schools for all learners. Boston: Allyn \& Bacon.

Pihko, M.-K. 2007. Minä, koulu ja englanti: Vertaileva tutkimus englanninkielisen sisällönopetuksen ja perinteisen englannin opetuksen affektiivisista tuloksista [Me, school and English: A comparative study of the affective outcomes of English teaching in Content and Language Integrated (CLIL) classes and in traditional foreign language classes]. University of Jyväskylä, FIN: Department of Teacher Education.

Pihko, M.-K. 2010. Vieras kieli kouluopiskelun välineenä: Oppilaiden kokemuksista vihjeitä CLIL-opetuksen kehittämiseen [Learning through a foreign language: Learners' personal learning experiences as a source of ideas for developing pedagogical practices in 
Content and Language Integrated Learning (CLIL) classes]. University of Jyväskylä, FIN: Department of Teacher Education.

Qian, D.D. 2004. Second language lexical inferencing: Preferences, perceptions, and practices. In Vocabulary in a second language: Selection, acquisition, and testing, ed. P. Bogaards and B. Laufer, 155-169. Amsterdam: John Benjamins Publishing Company.

Reis, S.M., D.B. McCoach, C.A. Little, L.M. Muller, and R.B. Kaniskan. 2011. The effects of differentiated instruction and enrichment pedagogy on reading achievement in five elementary schools. American Educational Research Journal 48, no. 2: 462-501.

Ruiz de Zarobe, Y. 2008. CLIL and foreign language learning: A longitudinal study in the Basque country. International CLIL Research Journal 1, no. 1: 60-73.

Saloviita, T. 2009. Inclusive education in Finland: A thwarted development. Zeitschrift für Inklusion 1. http://www.inklusion-online.net/index.php/inklusion/article/viewArticle/18/ 29

Seikkula-Leino, J. 2005. Oppilaan tukeminen vieraskielisessä opetuksessa [Supporting the pupil in CLIL education]. Tempus 5: 20-21.

Seikkula-Leino, J. 2007. CLIL learning: Achievement levels and affective factors. Language and Education 21, no. 4: 328-341.

Seppälä, R., and E. Kautto-Knape. 2009. Eriyttämisen tavat englannin opetuksessa [The ways of differentiating in English language education]. Kielikukko 4: 13-18.

Tomlinson, C.A. 1999. Differentiated classroom: Responding to the needs of all learners. Alexandria: ASCD.

Tomlinson, C.A., and S.D. Allan. 2000. Leadership for differentiating schools and classrooms. Alexandria: ASCD.

Tomlinson, C.A., K. Brimijoin, and L. Narvaez. 2008. The differentiated school: Making revolutionary changes in teaching and learning. Alexandria: ASCD.

Tomlinson, C.A., and C.C. Eidson. 2003. Differentiation in practice. A resource guide for differentiating curriculum, grades 5-9. Alexandria: ASCD.

Tomlinson, C.A., and M.B. Imbeau. 2010. Leading and managing a differentiated classroom. Alexandria: ASCD.

Tuomi, J., and A. Sarajärvi. 2009. Laadullinen tutkimus ja sisällönanalyysi [Qualitative research and content analysis]. 6th ed. Helsinki, FIN: Tammi.

UNESCO 2004. Changing teaching practices: Using curriculum differentiation to respond to students' diversity. http://unesdoc.unesco.org/images/0013/001365/136583e.pdf

Vygotsky, L.S. 1978. Mind in society: The development of higher psychological processes. Trans. and ed. M. Cole, V. John-Steiner, S. Scribner, and E. Souberman. Cambridge: Harvard University Press.

Vygotsky, L.S. 1982. Ajattelu ja kieli [Thought and language]. Trans. and ed. K. Helkama and A. Koski-Jännes. Espoo, FIN: Weilin+Göös.

Yatvin, J. 2004. A room with a differentiated view: How to serve all children as individual learners. Portsmouth: Heinemann. 
Table 1. The summed variables and the values of Cronbach's alpha in the quantitative phase of the research

\section{Topic and the number of variables}

\section{Cronbach's alpha}

differentiation for gifted pupils (5 variables)

0.62

perceptions of differentiation

(4 variables)

0.63

methods which can be used for both

dimensions of differentiation

0.71

(10 variables)

differentiation for underachieving pupils

(15 variables)

0.75

challenges of differentiation

(11 variables)

0.78

(11 variables)


Table 2. The participants in the qualitative phase of the research

\begin{tabular}{llll} 
Gender & Teacher 1 & Teacher 2 & Teacher 3 \\
\hline $\begin{array}{l}\text { Teaching } \\
\text { experience }\end{array}$ & female & female & male \\
\hline $\begin{array}{l}\text { Experience in } \\
\text { teaching CLIL }\end{array}$ & 20 years & 25 years & 7 years \\
\hline Grade & $\begin{array}{l}\text { 2nd } \\
\text { (age 8-9) }\end{array}$ & $\begin{array}{l}\text { 5th \& 6th } \\
\text { (age 11-13) }\end{array}$ & $\begin{array}{l}\text { 5th } \\
\text { (age 11-12) }\end{array}$ \\
\hline Pupils & 19 & 44 & 19 \\
\hline & $\begin{array}{l}\text { 0 received } \\
\text { special-needs } \\
\text { support }\end{array}$ & $\begin{array}{l}5 \text { received } \\
\text { special-needs } \\
\text { support }\end{array}$ & $\begin{array}{l}\text { 4 received } \\
\text { special-needs } \\
\text { support }\end{array}$ \\
$\begin{array}{l}\text { Pupils with } \\
\text { special needs }\end{array}$ & $\begin{array}{l}\text { received } \\
\text { enhanced } \\
\text { support }\end{array}$ & & \\
\hline Gifted pupils & 3 & 5 & $2-4$ \\
\hline
\end{tabular}


Table 3. The most commonly used differentiation methods for underachieving pupils the teachers $(n=44)$ used in CLIL education

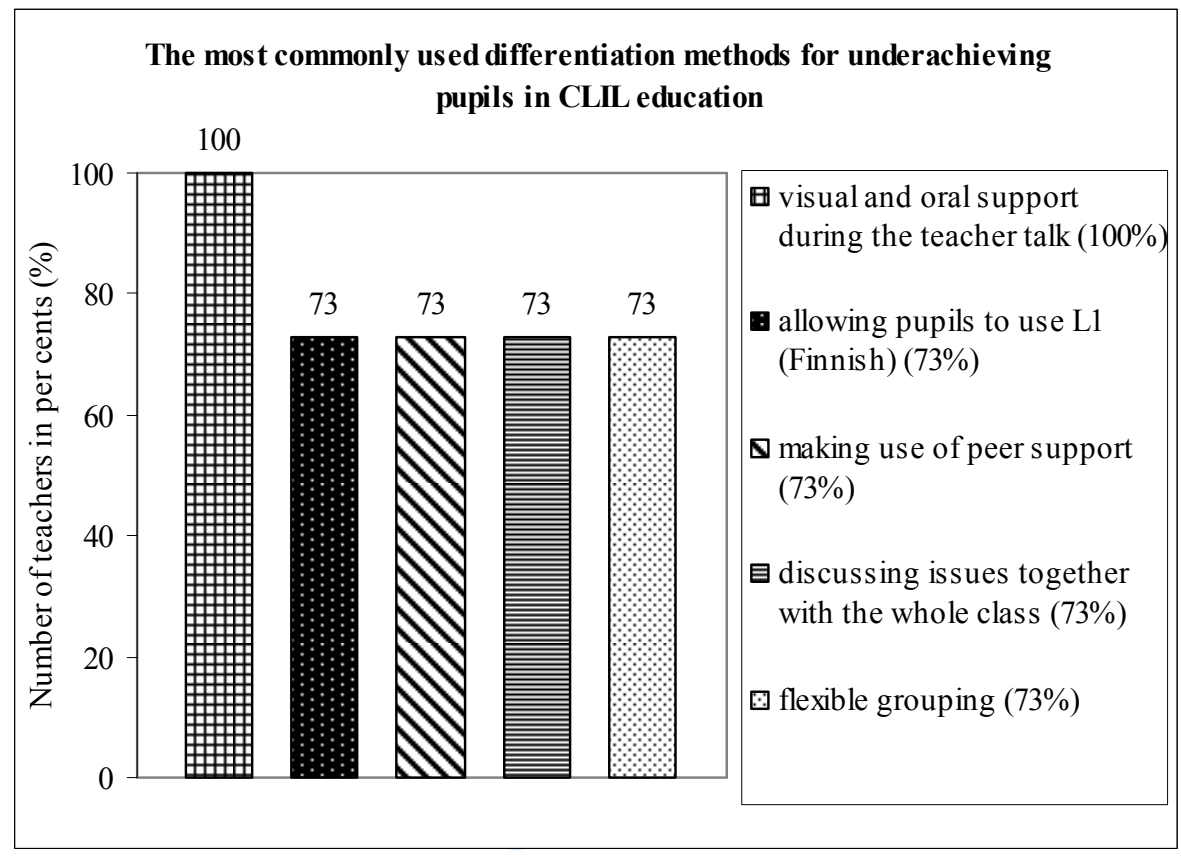


Table 4. The most commonly used differentiation methods for gifted pupils the teachers $(n=44)$ used in CLIL education

\begin{tabular}{|ll|l|l|}
\hline \multicolumn{5}{|c|}{ The most commonly us ed differentiation methods for gifted pupils in } \\
CLIL education
\end{tabular}


Table 5. The most commonly used methods that can be used for both dimensions of differentiation which the teachers $(n=44)$ used in CLIL education

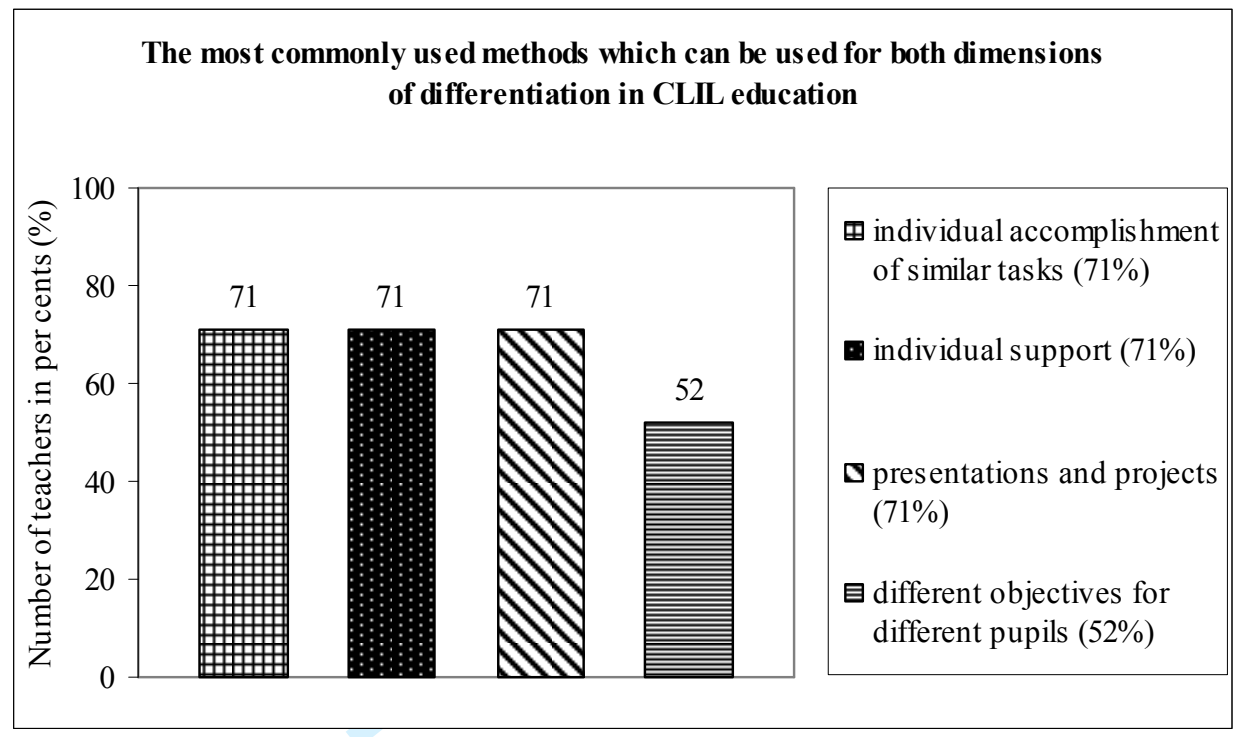


Table 6. The greatest challenges of differentiation in CLIL education the teachers $(n=41)$ identified

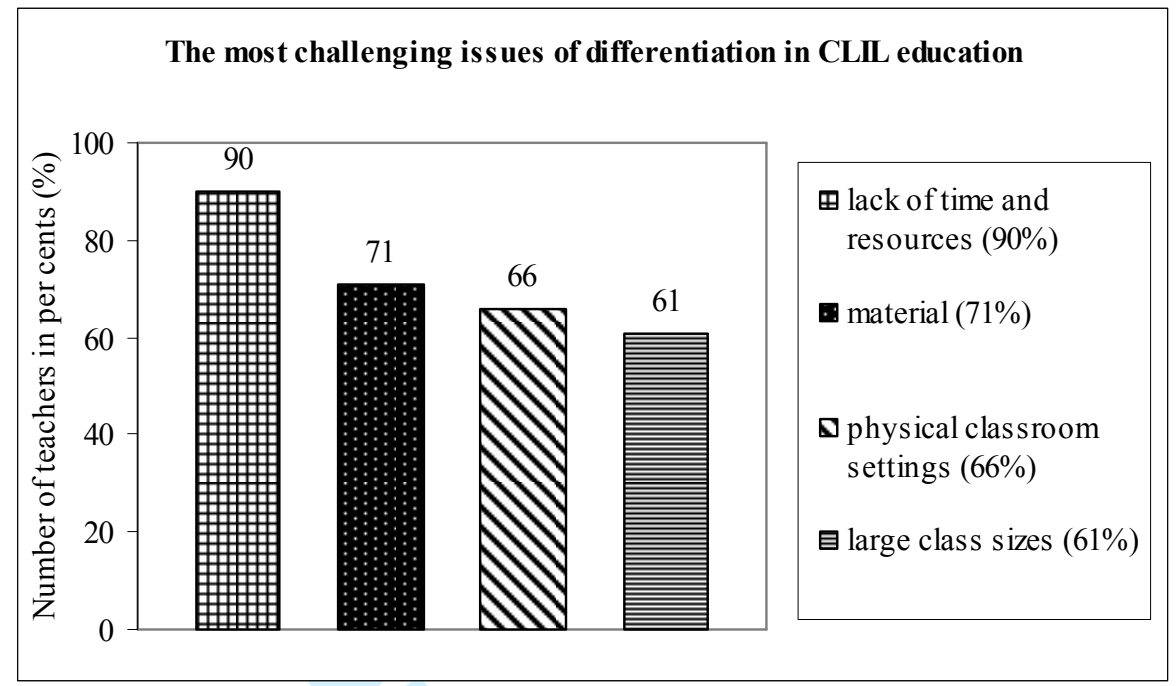


Table 7. The least challenging issues of differentiation in CLIL education the teachers $(n=41)$ identified

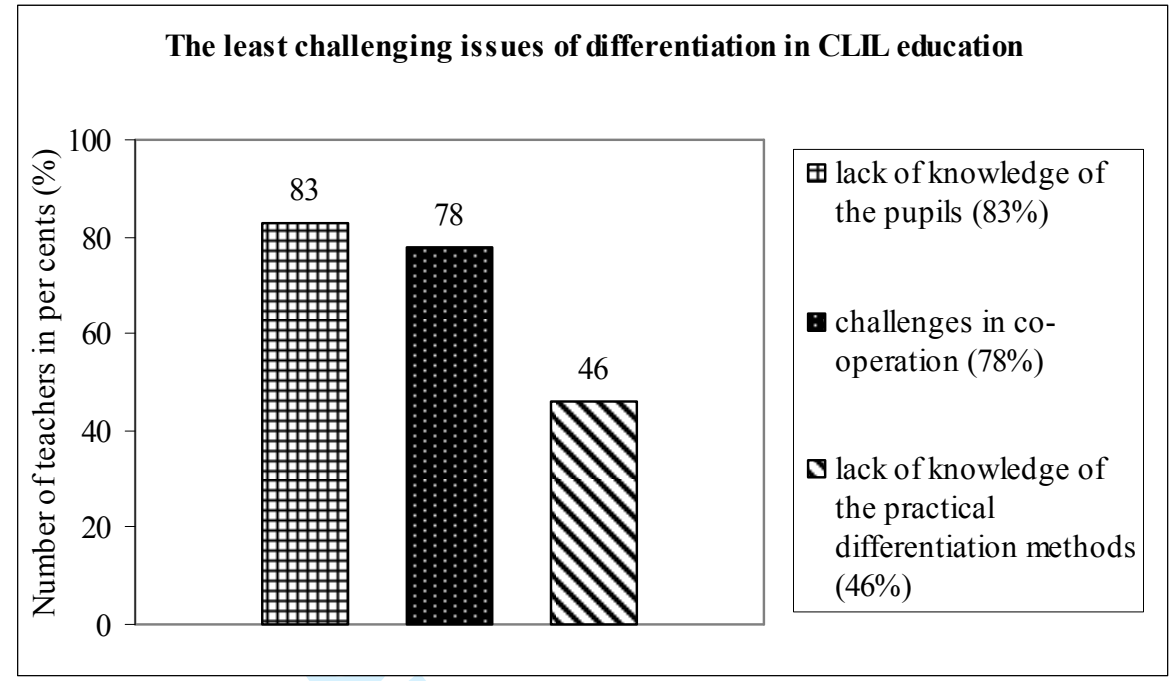


Figure 1. Differentiation in practice (Adapted from Tomlinson 1999; Moberg and Vehmas 2009; UNESCO 2004; Ikonen, Ojala and Virtanen 2003; AANCCBE 2010) 


\section{Word count:}

Abstract + key words $=199$ words

Text (headings, text, tables, references) $=7426$ words 


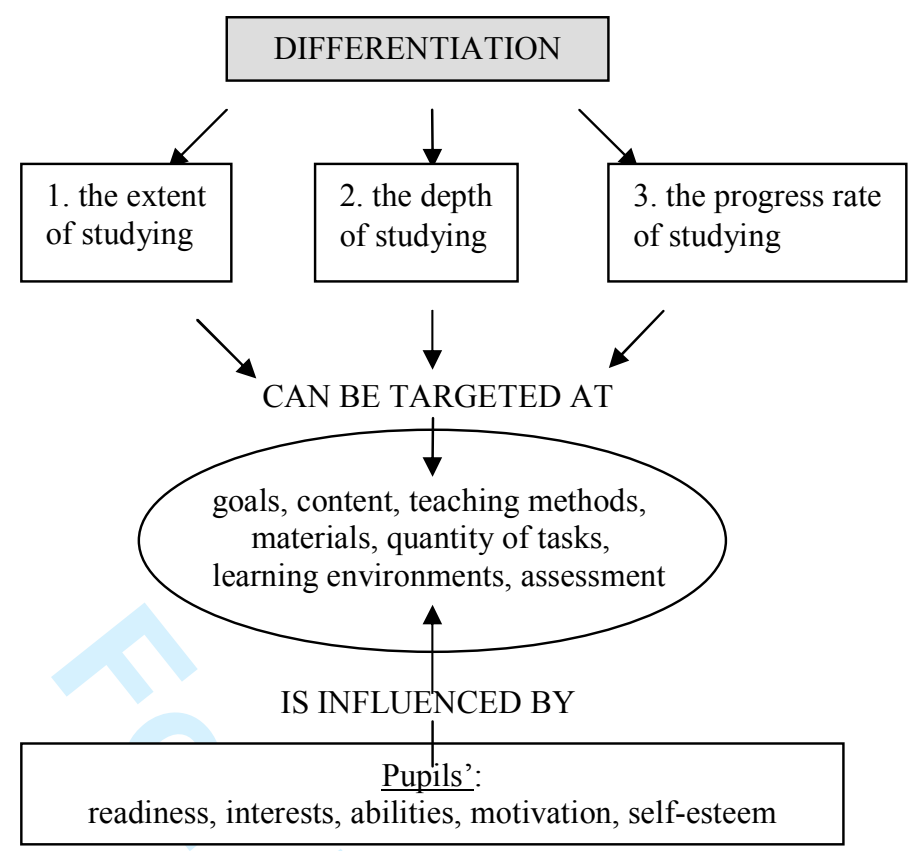

